\title{
De huisarts blijft!
}

Citation for published version (APA):

Metsemakers, J. F. M. (2003). De huisarts blijtt! Maastricht University. https://doi.org/10.26481/spe.20030926jm

Document status and date:

Published: 26/09/2003

DOI:

10.26481/spe.20030926jm

Document Version:

Publisher's PDF, also known as Version of record

\section{Please check the document version of this publication:}

- A submitted manuscript is the version of the article upon submission and before peer-review. There can be important differences between the submitted version and the official published version of record.

People interested in the research are advised to contact the author for the final version of the publication, or visit the DOI to the publisher's website.

- The final author version and the galley proof are versions of the publication after peer review.

- The final published version features the final layout of the paper including the volume, issue and page numbers.

Link to publication

\footnotetext{
General rights rights.

- You may freely distribute the URL identifying the publication in the public portal. please follow below link for the End User Agreement:

www.umlib.nl/taverne-license

Take down policy

If you believe that this document breaches copyright please contact us at:

repository@maastrichtuniversity.nl

providing details and we will investigate your claim.
}

Copyright and moral rights for the publications made accessible in the public portal are retained by the authors and/or other copyright owners and it is a condition of accessing publications that users recognise and abide by the legal requirements associated with these

- Users may download and print one copy of any publication from the public portal for the purpose of private study or research.

- You may not further distribute the material or use it for any profit-making activity or commercial gain

If the publication is distributed under the terms of Article $25 \mathrm{fa}$ of the Dutch Copyright Act, indicated by the "Taverne" license above, 
De huisarts blijft! 


\section{Colafon}

Basisantwerp en realisatie: Unigraphic, Uniwersiteit Maastricht

$156 \mathrm{~N} 90.568+9878$

nur: 870

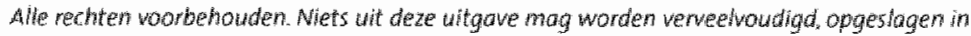
een geautomatiseed ge gevenbestand of openbaor gemaokt, zonder woorafgoande schriftelojke toestemming wan de auteur of uitgever. 


\section{De huisarts blijft!}

Oratie

uitgesproken door

Prof. Dr. Job F.M. Metsemakers

Hoogleraar Huisartsgeneeskunde

Maastricht, 26 september 2003

v

(M) Universiteit Maastricht 

Mijnheer de Rector Magnificus

Zeer geachte toehoorders

In de opleiding tot arts leren we studenten niet om slecht nieuws heen te draaien maar om het direct en duidelijk ter sprake te brengen.

Over de huisarts en de huisartsgeneeskunde is de laatste jaren nogal wat slecht nieuws verteld en geschreven.

- De Eerstelijnszorg doolt regieloos rond

- Artsen (bedoeld huisartsen) passen zich te langzaam aan

- Patiënt op naam gaat verdwijnen. Basils huisartsenzorg ondermijnd.

- Parttime in wissewasjes

Wij hebben als huisartsen zelf ook slecht nieuws verspreid

- We worden onvoldoende gehonoreerd

- We hebben teveel administratie

- We zijn overbelast

- Er komt een huisartsentekort

Het Capaciteitsorgaan dat tot taak heeft te berekenen hoeveel artsen in de toekomst nodig zijn heeft verschillende varianten doorgerekend. $k$ zall $u$ niet vermoeien met een opsomming van verschillende mogelijkheden om het toekomstige tekort te verkleinen. De eindconclusie blijft dat er een tekort zal ontstaan en de Landelijke Huisartsen Vereniging (LHV) heeft de vrees uitgesproken dat in 2006 vier tot vilf miljoen Nederlanders zonder huisarts zullen zitten.

Het is niet verwonderlijk dat dhr Wiegel, de voorman van de Zorgverzekeraars suggereerde de huisarts maar op te heffen. En op de dag dat u mijn uitnodiging voor deze feestelijke bijeenkomst ontving publiceerde het Historisch Nieuwsblad een essay met de titel "Het Hoge woord de huisarts sterft uit" ".

Dames en Heren, toch geef ik mijn rede de titel "De Huisarts blijfl!". In het licht van het voorgaande verwacht $u$ nu mogelijk een aanpassing in de trant van "De Huisarts blift, maar niet lang meer"!

Nee, de Huisarts blijft

Ik heb geen twijfel over de voortdurende cruciale positie van de huisarts in de Nederlandse én Europese gezondheidszorg. Nederlandse huisartsen handelen $90 \%$ wan de gepresenteerde gezondheidsproblemen zelfstandig af. De essentie van de zorg die de huisarts levert wijzigt niet. |k zal dat dadelijk nader toelichten. 
Ik kan wel een andere toevoeging aan de titel doen. De huisarts blijft, maar de structuur van de huisartsenzorg zal fors veranderen, beter gezegd is deels al veranderd. En dat is op zich niet vreemd want onze maatschappij werandert. We spreken over een 24 uurs economie waarin de tijden waarop gewerkt wordt niet meer per definitie gekoppeld zijn aan de tijd dat het daglicht is. Vrouwen zijn in grote getale deel gaan nemen aan het arbeidsproces. Flexibele arbeidstijden hebben ervoor gezorgd dat het weekend voor velen al op vrijdagmiddag begint. ( $k$ ben dus zeer vereerd dat $u$ vrije tijd gebruikt om naar mij te komen luisteren).

De organisatie van de huisartsenzorg zall op die maatschappelijke veranderingen moeten inspelen.

Vercler is het nuttig en zelfs noodzakelijk dat wij huisartsen onze houding veranderen. Huisartsen klagen niet over de inhoud van het vak maar over de werkomstandigheden. De Nedlerlandse huisartsenzorg oogst lof in het buitenland ". Laten we dan ons enthouslasme over het vak zelf uitdiragen. Laten we trots zijn, laten we zelfbewust zijn. Joke Lanphen, woormalig voorzitter van de KNMG (Koninklijke Nederlandsche Maatschappij tot bevordering der Geneeskunst), voormalig bestuurslid van de LHV (de Landelijke Huisartsen Vereniging) maar bovenal huisarts zegt: "Huisartsen hebben een goede peptalk nodig" 3 .

De Huisarts blift! We stoppen met klagen, nemen het heft in eigen handen en gaan de zaken anders aanpakken. Als we het plezier in ons werk weer uitstralen wordt ons vak ook weer aantrekkelijk woor studenten die een beroepskeuze moeten maken.

Ik zal u eerst informeren over de kerntaken van de huisarts en de veranderingen in de structuur van de huisartsenzorg. Vervolgens zal ik onderwijs en wetenschappelijk onderzoek nader beschouwen en u een beeld geven van het huisartsgeneeskundig veld waarin en waarmee we die taken uitwoeren. Tenslotte zal ik aandacht besteden aan het internationale karakter van onze activiteiten.

Huisartsen weten dat het aantal belangrijke boodschappen dat een patiênt kam onthouden en thuis kan reproduceren niet groter dan 3 is. Bovendien is thet verstandig de boodschappen te herhalen. Ik geef u daarom nu reeds de drie boodschappen waarvan de eerste u inmiddels duidelijk is. 
- De huisarts blifft! Er komen grotere huisartsenzorg voorzieningen met andere goed opgeleide professionals die taken van de huisarts overnemen.

De tweede boodschap is samen te vatten als:

- De opzet en wijze van nascholing van de huisarts zal drastisch veranderen. De verdere scholing zal, gerelateerd aan kwaliteitsbevordering van de praktijk. gebaseerd zijn op gemeten leerbehoeften en niet meer op de vrijblijvende keuzes van de huisarts.

Tenslotte de derde boodschap om te onthouden:

- Naast de toenemende samenwerking in het kader van het onderwijs met een groot aantal huisartspraktijken, zal de huidige ietwat vrijblijvende samenwerking van de capaciteitsgroep met de academische praktijken worden orngevormd tot een hecht netwerk dat een ontwikkelfunctie heeft voor onderwijs, onderzoek en met name zorginnovatie.

Sommige dingen lijken zo vanzelfsprekend dat we er niet bij stilstaan dat ze ooit anders waren of zouden kunnen worden. $1 k$ heb $u$ in het begin van mijn rede enkele krantenkoppen laten zien waarin de huisartsgeneeskunde een sombere toekomst werd woorspeld. $U$ als patient was wellicht werbaasd maar ook huisartsen waren dat. Ze deden met plezier hun werk en toch veranderde plotseling de wereld waarin ze werkten. Zorgverzekeraars probeerden te bepalen hoe de gezondheidszorg zou moetem worden georganiseerd en de overheid lijkt steeds kortzichtiger en onbetrouwbaarder te worden. Een woorbeeld is het plots stopzetten van de subsidies aan het Nederlands. Huisartsen Genootschap (NHG) en de Landelijke Huisartsen Vereniging (LHV). Kortzichtig omdat de gelden gebruikt werden voor het bevorderen van de kwaliteit van de huisartsenzorg. Onbetrouwbaar omdat enkele dagen woor de afkondiging van de subsidiestop toegezegd was dat niet op de huisartsenzorg gekort zou worden si.

Er was ook onrust in de beroepsgroep zelf over onze taak en functie in de toekomst. Het Basistakenpakket was sinds 1984 niet essentieel meer bijgesteld terwijl er zowel in de maatschappij als in de medische wetenschap duidelijk veranderingen waren opgetreden "I noem er enkele:

- veranderingen in de pattëntenpopulatie, als gevolg van vergrijzing en toename van het aantal allochtone Nederlanders 
- een verandering van de hulpvraag door de toename van meer en beter geinformeerde patienten met behoefte aan advies en begeleiding door de huisarts

- discussies over de irrichting van het zorgstelsel en de financiering van de hulsartsenzorg

- snelle ontwikkelingen in de medisch wetenschap ${ }^{\text {bi }}$.

Het was duidelijk dat de beroepsgroep in het licht van deze ontwikkelingen zelf duidelijk moest verwoorden wat van haar verwacht kan worden. De Landelijke Huisartsen Vereniging (LHV) en het Nederlands Huisartsen Genootschap (NHG) hebben in 2001 samen het project Toekomstvisie Huisartsenzorg ter hand genomen ").

De essentie van de zorg zal niet veranderen. In de Toekomstvisie Huisartsenzorg wordt dat in fraaie volzinnen beschreven. Ik zal me nu beperken tot enkele essentiële kernbegrippen.

De Huisartsenzorg blijft generalistisch

- Ze rekent alle klachten, problemen en vragen die over gezondheid en zlekte door individuele patienten gepresenteerd worden tot haar taakgebied. Ze beperkt zich niet tot bepaalde patiëntengroepen of aandoeningen maar richt zich op de totale patientenpopulatie en het complete spectrum aan gezondheidsklachten

- Klachten en aandoeningen worden daarbij niet geisoleerd beschouwd, maar gezien in hun onderlinge relatie en in hun relatie met bestaande ziekten en aandoeningen

De Huisartsenzorg blijft direct toegankelijk

- dat moet niet begrepen worden als bimnen lopen en geholpen worden, maar als zonder drempels voor wie dan ook

De Huisartsenzorg blifft continuiteit in de relatie nastreven

- er zal duidelijke overdracht wan zorg moeten zijn bij het toenemend aantal parttime werkende huisartsen en andere hulpverleners

De Huisartsenzorg blijft context gericht

- dat wil zeggen dat levensloop, culturele, persoonlijke en existentiele opvattingen van de patiënt betrokken worden bij het hulpverleningsproces evenals zijin woon, werk, en leefomgeving

De Hulsartsenzorg blift regiefunctie vervullen

- hieronder valt enerzijds de poortwachtersrol voor de toegang tot andere delen van het zorgsysteem, maar ook de coördinatierol wanneer de zorgverlening door verschillende hulpverleners wordt ver- 
strekt. Ten aanzien van de patiënt fungeert hij als een gids: hij helpt bij het maken wan keuzes

De manier van werken van huisartsen en de organisatie van de huisartsenzorg zal wel veranderen. Ik citeer nu uit de Toekomstvisie Huisartsenzorg

"Huisartsen willen hun zorg in de toekomst steeds meer bieden wanuit de huisartsgeneeskundige woorziening die kleinschalig van aard is en beschikbaar in de nabijheid van de patient. Binnen deze vooriening zullen huisartsen samenwerken en zal taakdelegatie en taakdifferentiatie platsvinden."

Maar hoe groot is kleinschalig van aard en wat bedoelen we met "de nabijheid van de patiënt"? In de verdere uitwerking wordt dan veelal de term "wijkgebonden" gehanteerd.

Laten we naar twee gebieden kijken waar planmatig met de gezondheidszorg is omgegaan. In Almere, in 1975 ontstaan, wonen nu 165.000 inwoners waarvoor 20 gezond heidscentra zijn opgezet. Dat houdt in dat elk centrum ongeveer 8.200 patiënten telt. Almere groelt nog steeds stevig en de huidige centra zullen deze graei grotendeels moeten opvangen. In de Leidsche Rijn, een volledige nieuwe stadsdeel van Utrecht zullen per 2015 in totaal goooo mensen wonen. Daarvoor worden 7 wijkgezondheidscentra voorzlen. Dat zijn 13.000 patiënten per centrum. De ervaringen leren dat 10.000-12.000 patiënten een goede omvang is voor een kleinschalige voorziening.

Wat zijn dan de consequenties voor Maastricht. Maastricht heeft 7 wijken, iets meer dan 122.000 inwoners en op dit moment 33 huisartspraktijken en gezondheidscentra. Uitgaande van bovengenoemd getal zou dat betekenen dat in Maastricht 10-12 huisartsvoorzieningen zouden ontstaan war per centrum 5-6 deets parttime werkende huisartsen werkzaarn zijn. Dat is een hele verandering. Dat ontstaat niet van vandaag op morgen maar het is wel de consequentie van de toekomstvisie Huisartsenzorg. We zullen die als uitgangspunt moeten nemen. Bij de uitwerking moeten we natuurlijk rekening houden met geografische en culturele aspecten. Het gaat immers om "kleinschalig" en "nabijheid". Deze afwegingen gelden nog duidelijker als het gaat om niet stedelijke of verstedelijkte gebieden. Maar het leidt geen twijfel dat de solo praktijk en de dwo praktijk zeker in het verstedelijkt gebied niet meer passen. 
Dat is geen diskwalificatie van hun huidige functioneren maar een logische consequentie gegeven de veranderingen in de zorgstructuren.

Een andere vraag is of al deze huisartsenzorgvoorzieningen zelfstandige eenheden zijn. Naar mijn mening niet. lk voorzie op organisatorisch bestuurlijk gebled grotere eenheden die meerdere huisartsenzorgvoorzienirigen onder hun beheer hebben.

Welke parti] moet het voortouw nemen bij die toekomstige ontwikkeling? Is dat de Districts Huisartsen Vereniging (DHW) of de Regionale Huisartsen Vereniging (RHV)? Dat lijkt logisch maar hun consensusmodel dat inherent is aan hun verenigingsstructuur werkt vertragend. Gaan de ziekenhuizen, die steeds beter begrijpen dat een goed functionerende eerste lijn een belangrijke voorwaarde is voor hun eigen functïoneren, actief worden? Ziekenhuizen hebben veel organisatorische expertise, en evaring in de omgang met zorgverzekeraars. Maar, zullen huisartsen zich dan niet bedreigd voelen? Grote twijfel heb ik bij een eventuele rol van zorgverzekeraars op dit gebied. Op enkele plaatsen hebben ze, volgens hun zeggen uit nood geboren, een actleve rol gespeeld en in eigen beheer een huisartsvoorziening opgezet ${ }^{\text {: }}$. Ik beschouw dit als een ongewenste ontwikkeling omdat andere, lees financiële, motieven een rol zouden kunnen gaan spelen bij het functioneren van de huisartsenzorgvoorziening. Alle professionele autonomie wan de huisarts ten splft zal er toch een voortdurende onzekerheid bestaan over de toekomstige koers. Er is nog een partij die wellswaar op een andere wijze betrokken is of zou moeten zijn en dat is de gemeentelijke overheid. Als we praten over wijkgebonden huisartsenzorgvoorzieningen dan zal dat consequenties hebben voor de ruimtelijke orde. ning. Verwacht mag worden dat gemeentes een pro actieve rol gaan vervullen want de gemeente heeft een wettelijke verplichting om zorg te dragen voor het welzijn en de zorg woor haar burgers.

Kortom, ik denk dat afhankelijk van de lokale en regionale omstandigheden verschillende partijen met elkar aan de slag zullen moeten gaan. Samenwerking met ziekenhuizen, zorgverzekeraars en gemeenten is noodzakelijk maar laat huisartsen de koers en de regie bepalen. Wij huisartsen moeten de eerste stap zetten en als dat niet door de DHV of RHV gebeurt zullen ondernemende huisartsen zelf aan de slag gaan.

Laten we terugkijken naar het andere deel van de beschrijving wan de huisartsenzorgvoorziening die luidde: Binnen deze woorziening zullen 
huisartsen samenwerken en zal taakdelegatie en täakdifferentiatie plaatsvinden.

De waarde van goede samenwerking en afspraken met andere werkers in de eerste lijn, alsook met ziekenhuizen in de vorm van afspraken over transmurale of ketenzorg kan niet genoeg benadrukt worden. De samenwerking met andere hulpwerleners zou idealiter moeten leiden tot samenwerking binnen éen gebouw: het wijk gezondheidscentrum $\$$.

Ik will nu aandacht besteden aan taakdelegatie warbij het in feite gaat om het structureel herverdelen van taken tussen verschillende beroepen ${ }^{\text {10l? }}$.

Deze herschikking heeft in de huisartsgeneeskunde de naam "Praktijk Ondersteuning Huisartsen" gekregen waarbij verschillende doelen wer* den gepresenteerd.

- Werkdrukvermindering voor de huisarts

- Kwaliteitsverbetering van met name de chronische zorg

- Verminderen van het capaciteitsprobleem van huisartsen

Er bestaat nog steeds twijfel over de haalbaarheid van deze doelen. Ook werd betoogd dat de praktijkondersteuning juist moest worden ingezet bij kleine kwalen amdat daar de meeste tijdswinst te behalen viel "m.

Het model dat in het weld het meest ontwikkeld wordt, gaat uit van ondersteuning bij de zorg voor chronische zieken. De praktijkondersteuner (verpleegkundige of doktersassistente met extra opleiding) neemt bijvoorbeeld bij een diabetespatient de 3 maandelijkse controles voor haar rekening, terwijl de huisarts de jaarlijkse grote controle uitvoert. Belangrijk is dat er voor dit hele proces een goed protocol is uitgewerkt, waaruit duidelijk blijkt dat de huisarts de regie behoudt en goed omschreven is wie, wat en wanneer doet.

In Limburg hebben: 278 huisartsen praktijkondersteuning en dat is $54 \%$ van de Limburgse huisartsen. Inmiddels bij jkt uit een eerste evaluatie dat huisartsen. praktijkondersteuners en patiënten redelijk tevreden zijn. Wetenschappelijk onderzoek laat zien dat de kwalliteit wan zorg goed is, en de acceptatie en tevredenheid groot " ${ }^{22 !}$. Het is dan ook onbegrijpelijk dat de overheid de zorgverzekeraars geen rumte geeft om dit proces met kracht verder uit te werken.

Naast de verandering in de zorg voor chronische patienten zien we ook meer aandacht woor de eerste fase van het contact van de patient met de huisartsenzorgvoorziening. Het begrip triage of instroommana. gement doet nu opgang. Doktersassistenten hebben altijd al aan triage gedaan ' Ze beoordelen wie er vondaag moet komen en wat kan wach- 
ten, of dat de huisarts met spoed een visite moet maken. In de huidige ontwikkeling van triage beoordeelt de doktersassistente welke hulpverlener de hulpvraag van de patiënt moet beantwoorden. Kan zij dat zelf op basis van een telefonisch protocol, is een consult bij de huisarts nodig, of is de patient te plaatsen bij de praktijkverpleegkundige? Deze ontwikkeling is mede het gevolg van de werkzaamheden van assistentes op de Huisartsenposten.

Hoever deze triage kan gaan, verdient gedegen studie. De hulpwraag van patienten is namelijk niet altijd even helder en wordt vaak pas in cen gesprek in relatie gebracht met leef-en woonomstandigheden.

We zullen, als we deze taakdelegatie/taakherschikking verder willen inwoeren, nadrukkelijker aandacht moeten schenken aan de geleverde kwaliteit wan zorg.

Daarnaast zullen we ook inwloed moeten uitoefenen op de opleidingen van deze met ons samenwerkende professionals.

Her en der wordt ook gesuggereerd dat de huisarts, als hij onder steuning heeft, een groter aantal patiënten in zijn praktijk zou kunmen opnemen. Wellicht wel 4.000 in plaats wan het huidige rekengetal van 2.350. Door dit soort berekeningen wordt het huisartsentekort ook weggepoetst. Laten we niet vergeten dat één van de doelen van taakverdeling werkdrukvermindering was. Enerzijds zal er geleidelijk tijd vrij komen, maar anderzijds leidt de transmurale zorg mogelijk weer tot een toename van de werkzaamheden. Het lijkt mij derhalve nog te vroeg om uit te gaan van een andere praktijkgrootte.

Wellicht verbaast het $u$ dat ik zo uitwoerig heb stilgestaan bij de Toekomstvisie Huisartsenzorg en bij enkele punten stelling heb genomen in het debat.

Ik zie het als een taak van de capaciteitsgroep Huisartsgeneeskunde en dus ook als mijn taak om er aan bij te dragen dat u ook in de toekomst goede huisartsenzorg krijgt. Naar mijn mening is het niet voldoende om een goede opleiding aan studenten en toekomstige hulisartsen te geven, of relevant huisartsgeneeskundig onderzoek te verrichten. We moeten als huisartsen van de capaciteitsgroep Huisartsgeneeskunde mede richting geven aan de ontwikkelingen in de huisartsenzorg. We moeten deelnemen aan en stelling nemen in het debat. Het is onze taak de vraag te stellen of we niet te maken hebben met de waan van de dag. Wij moeten nagaan of veranderingen ook verbeterin- 
gen zijn. We moeten die rol in kritische dialoog met alle huisartsen en andere hulpverleners vervullen.

\section{Onderwijs}

Bij de opening van het huidig academisch jaar sprak de voorzitter van het College van Bestuur van deze instelling de woorden: "We moeten het best mogelijke onderwijs verzorgen". Deze woorden geven het belang aan dat de Universiteit aan de primaire taak "Onderwijs" toekent. En Maastricht staat ook bekend om zijn kwalitatief goed en inno. vatiefonderwijs.

De Faculteit Geneeskunde heeft sinds 2001 haar curriculum herzien. Onze capaciteitsgroep levert zoals gewoonlijk een aanzienlijke bijdrage. In het derde studiejaar waarin chronische ziekten centraal staan, leveren we planningsgroepsleden, coaches (groepsbegeleiders) en hebben we het Adoptieprogramma omgewormol naar een programma Praktijkcontacten Huisartsgeneeskunde.

Studenten komen daarbij 10-11 maal in hun derde studiejaar bij de huisarts. Ze voeren opdrachten uit en rapporteren in hun basisgroep (= onderwijsgroep). De voorbereidingen voor een bijstelling van de 10 weekse Praktisch Medische Onderwijs stage in de Huisartspraktijk zijn begonnen. We spreken in onze onderwijsgroep over de plannen voor jaar 6. Goed werk allemaal. De Huisartsopleiding is bezig met de omvorming van een standaard opleidingsprogramma woor alle huisartsen in opleiding tot onderwijs op maat. De Eindtermen voor de Huisarts zijn geformuleerd. Er wordt onderzoek verricht naar de leereffecten van onderwijsprogramma's. Genoeg werk dus.

Ik wil op dit moment met een andere blik naar ons onderwijs kijken. Is er een doorlopende leerlijn: artsopleiding - huisartsopleiding nascholing/deskundigheidsbevordering? Hoe blijf je leren ofwel hoe word je een life long learner? Welke vaardigheid heb je daarvoor nodig? Die valardigheid moeten we studenten al in het basiscurriculum aanleren. We spreken over studentgecentreerd leren of adult learning. De kern is dat de lerende zelf, actief op zoek gaat naar datgene wat hij wil weten. We moeten studenten duidelijk maken welke motieven we hebben uit bijvoorbeeld de leerpsychologie om hun die leerwijze aan te bieden als basisvaardigheid. Wellicht dat de studenten die in het middelbaar onderwijs volgens de tweede fase structuur gestudeerd hebben een beter idee hebben van adult learning. Ik heb daar op basis van mijn eigen observatie in huiselijke kring wel twijfels over. Hoe het ook zij, het onder- 
wijsprogramma dient actief zelfstandig leren krachtig te stimuleren. In haar rapport "De Airts van Straks" over het medisch opleidingscontinuüm, constateert de verantwoordlelijke projectgroep dat er een zeer geringe aansluiting is van de initiele opleiding (basisarts) en de medische vervolgopleidingen (tot huisarts of bijwoorbeeld tot cardioloog), noch op inhoudelijk onderwijskundig, of organisatorisch gebied "Wij kumen en moeten dan ook met het rapport. "De Arts van Straks", en met het advies van de Commissle Implementatie Opleidingscontiniuüm en Taakherschikking gaan werken aan een veel betere aansluiting van basiscurriculum en huisartsopleiding ${ }^{\text {aj. }}$. Een aantal elementen van het rapport is inmiddels al in het hernieuwde curriculum 2001 van de Faculteit Geneeskunde opgenomen, met name in die van het schakeljaar. In die gedachte zou jaar 6 naast een wetenschapsstage bestaan uit een beperkt aantal klinische stages warin de student met grotere zelfstandigheid en verantwoordelijkheid werkt. Wellicht zou dat ook tot werkorting van de medische vervolgopleiding kunnen leiden.

Het opleidingscontinuüm is daarmee nog niet compleet. Ook woor de fase nà de huisartsopleiding zal de capaciteitsgroep Huisartsgeneeskunde mede-verantwoordelijkheid moeten uitstralen en waarmaken.

Binnen die nascholing bestaan inmiddels verschillende termen.

- Onderwijs am bij te blijven

CME Continuous Medical Education

Kennis en vaardigheden medisch gebied

CPD Continuous Professional Development

Kennis en vaardigheden medisch, management, en persoonlijk gebied

- Verdiepingsonderwijs HPD Higher Professional Development

Kennis en vaardigheden op een zeer specifiek onderwerp

Nederland kent daartoe onder andere de kaderopleiding en we spreken dan van een huisarts inet differentiatie.

Ik wil nu nader ingaan op de huidige gang van zaken rond de gebruikelijke nascholing (CME). Deze is sterk gekoppeld aan het proces wan herregistratie. Elke huisarts dient orn de 5 jaar ten behoeve van zijn herregistratie aan te tonen dat hij in voldoende mate als huisarts werkt en gemidideld 40 nascholingsuren per jaar heeft gevolgd bij goedgekeurde bijeenkomsten. 
Hobma schreef hierover een fraaie zin en ik citeer:

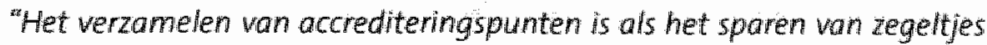
bij de supermarkt: gaandeweg sprokkel je ze wel bij elkaar, maar als je een vol boekje inlevert, is het maar de vraag of je er iets beter van wordt"

We weten uit verschillende onderzoeken dat huisartsen naar de verkeerde cursussen gaan. Ze gaan niet naar cursussen over onderwerpen waar ze "niets" van af weten. Bovendien blijkt de effectiviteit van deze nascholing zeer gering, omdat de "need to know", een belangrijke drijfveer bij adult learning, heel gering is. Logisch, want de huisarts koos een onderwerp waar hij al veel vanaf wist. Verder zijn er weinig cursussen gebaseerd op het principe van actief leren op basis van zelfstandig geformuleerde leerdoelen. We zullen derhalve af moeten van het systeem waarbij de huisarts op basis van de fraaiste folder, de mooiste accommodatie kiest voor een cursus die hij niet nodig heeft.

Hij moet zijn keuzes niet baseren op wat hij dénkt dat nuttig is, maar op basis van wat blijkt dat nodig is. Er is inmiddels een aantal instrumenten uit het domein van kwaliteitsbevordering (Quality Development) zoals het Visitatie Instrument Praktijk (VIP), de VIP plus, video observatie, kennistoetsen ter beschikking mas . Deze geven op praktijk- en/of individueel niveau een score die vergeleken wordt met de score van een vergelijkbare groep praktijken of huisartsen. Op basis daarvan kunnen veranderpunten op praktijkniveau of leerdoelen op individueel niveau worden bepaald.

Hoewel nog niet wolledig en afdoende is bewezen dat een dergelijke aanpak ook leidt tot een betere kwaliteit van zorg, ben ik van mening dat er afdoende bewijs is voor het feit dat de huidige nascholingsaan-

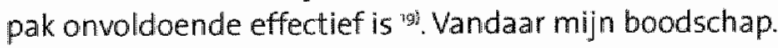

De opzet en wijze van nascholing van de huisarts zal drastisch moeten veranderen. De verdere scholing zal, gerelateerd aan kwaliteitsbevordering van de praktijk, gebaseerd $z i j n$ op gemeten leerbehoeften en niet meer op de vrijblijvende keuzes van de huisarts.

\section{Wetenschappelijk onderzoek}

De capaciteitsgroep Huisartsgeneeskunde levert een ruime bljdrage aan het wetenschappelijk onderzoek van deze instelling. Aanvankelijk was het onderzoek ondergebracht in het onderzoeksinstituut Extra en Transmurale Research (ExTra) dat recent is getransformeerd tot Caphri (Care and Public Health Research Institute).

Ons onderzoek is gebaseerd op vragen uit de zorg zowel van patiénten 
als zorgwenteners. We bestuderen zowel de effectiviteit van diagnostisch handelen (welke wrag of welke bevinding helpt de huisarts nu het meest om een goede diagnose te stellen) alsook de effectiviteit van the rapeutisch handelen (heeft aanpak $A$ nu duidelijk beter resultaat dan aanpak B). We richten ons daarbij met name op enkele gebieden: hart en vaten, de buik, astma/COPD en het bewegingsapparaat.

Verder zijn we nadrukkelijk actief in het onderzoek naar kwaliteit van zorg (wordt zorg geleverd zoals in afspraken vastgelegd of hoe kunnen we de kwaliteit van de zorg verbeteren).

Een aantal van deze onderzoeksprojecten is verricht met gegevens van het RegistratieNet Huisartspraktijken (RNH). Er zijn 22 huisartspraktijken die gegevens verzamelen ten behoeve van een dynamisch geanonimiseerd patiëntenbestand. Deze gegevens zijn voor onderzoekers beschikbaar als steekproefkader, walarop ook transversale en longitudinale analyses verricht kunnen worden. Een aantal promoties wan academische huisartsen, onderzoekers van de Faculteit Geneeskunde, de Faculteit Gezondheidswetenschappen, en het azM is tot stand gekomen op basis van gegevens uit het RNH. Het grote belang van dergelijke huisartsgeneeskundige registraties werd in 2002 nog eens benadrulkt toen het Amerikaanse Instituut woor Gezondheidszorgonderzoek en Kwaliteitszorg besloot de infrastructuur van bestaande Practice based research networks (netwerken vergelijkbaar met het $\mathrm{RNH}$ ) financieel te garanderen en onderzoeksprojecten te stimuleren ${ }^{2 \%}$. Juist deze netwerken zijn in staat gebruik te maken van beschikbare gegevens uit de zorgregistraties en deze te combineren met additioneel verkregen onderzoeksgegevens.

Deze aanpak hebben we in Maastricht ook gekozen voor het SMILE project. SMILE staat voor Studie Medische Informatie \& Leefwijzen Eindhoven. In die studie ontvangen alle patiënten van de deelnemende gezondheidscentra van de Stichting Gezondheidscentra Eindhoven die 12 Jaar en ouder zijn, circa 2 maal per jaar een vragenlijst. Patienten worden gevraagd naar aspecten van hun leefwijze, terwijl de huisartsen relevante zorggegevens zoals ziektes en medicingebruik verzamelen. Het zal u duidelijk zijn dat zeer uitvoerig aandacht is besteed aan privacy aspecten. De eerste veelbelovende stappen zijn gezet.

Reeds eerder heb ik aangegeven dat huisartsen steeds meer te maken krijgen met transmurale zorg, oftewel verschuivingen in de zorg. Dat proces is al enige tijd aan de gang. De patiënt hoeft na een knie- 
operatie niet meer twee weken in het ziekenhuis te blijwen maar wordt na twee dagen al naar huis ontslagen. Patienten worden niet meer standaard opgenomen woor een meerdaagse chemokuur maar ze mogen "s avonds weer thuis gaan slapen. Beide voorbeeliden lijken zeer patiëntvriendelijk. De patient is immers eerder in zijn oude vertrouwde omgeving. Huisartsen ervoeren dit beleid in den beginne als zeer huisartsonvriendelijk omdat er geen overleg gevoerd werd over de nazorg.

Gelukkig wordt nu bij deze verschuiving van zorg duidelijk omschreven welke professional in welke fase van de zorgketen wat doet. Zo wordt zorg afgestemd.

Maar zijn al deze veranderingen nu ook verbeteringen en wat kost dat dan> Deze vragen dienen wel beantwoord te worden. Hier ligt de uitda* ging in de samenwerking met de afdeling Transmurale zorg van het academisch ziekenhuis waar we onderzoek naar vernieuwing en verandering van ketenzorg met betrekking tot kwaliteit, effectiviteit, en doelmatigheid willen opzetten. Gelukkig bestaat er reeds een traditie van onderzoek op dat gebied waarop we nu krachtig kunnen woortbouwen.

Ik zel eerder dat ons onderzoek is gebaseerd op vragen uit de zorg zowel van patienten en zorgverleners. Vanuit dat perspectief wordt vanuit onze groep onderzoek gedaan naar de zorg voor mensen met een verstandelijke beperking. De zorg voor deze mensen zal in toenemende mate verleend gaan worden door de huisarts omdat de grote verblijfsinstellingen worden ontmanteld en bewoners steeds meer in de wijk komen wonen. Er zijn nog veel vragen die beantwoord moeten worden. Het onderzoek past binnen onze kernbegrippen Effectiviteit van handelen en Kwaliteit van zorg. Bovendien is er sprake van een forse verandering in de zorgketenstructuur.

Om onderzoek te doen heb je ondlerzoekers nodig en liefst onderzoekers die feeling hebben met huisartsgeneeskunde. Veelal zijn dat ervaren huisartsen of artsen die huisarts willen worden. Gelukkig hebben we in onze capaciteitsgroep met beide te doen. Met name het feit dat we een gecombineerde opleiding van huisarts en onderzoeker, met de prachtige afkorting AIOTHO, kunnen aanbieden geeft mij vertrouwen in dle toekomst van het huisartsgeneeskundig onderzoek van onze capaciteitsgroep.

\section{Het huisartsgeneeskundige veld}

In het eerste jaar van mijn studie geneeskunde aan de net gestarte Medische Faculteit Maastricht, wilde de Faculteit een 4.daagse "kijk en doe" stage bij de huisarts organiseren. Dat was een grote opgave: er 
moesten 49 studenten worden geplaatst. Enkele jaren later wilde de capaciteitsgroep de studenten 12 weken stage laten lopen in een huisartspraktijk. Dat was uniek in Nedertand en er moest flink wat werk verricht worden om huisartsen duidelijk te maken dat dit Praktisch Medisch Onderwijs in de Huisartspraktijk (PMO-H) verantwoord was.

Tijden zijn veranderd. We hebben dit curriculumjaar 34 eerstejaars studenten geneeskunde. Op dit moment heeft de capaciteitsgroep ervoor gezorgd dat 240 studenten in hun derde studiejaar 10-11 maal een huisartspraktijk kunnen bezoeken voor contacten met patiënten. Voor de PMO-H stage zullen we dit jaar 242 stageplekken aanleveren.

In Limburg verleent $61 \%$ van de huisartsen aan een of meer studenten uit het basiscurriculum gastvrijheid, terwijl dat in Brabant $50 \%$ is. Daamaast namen in 2002 in Limburg 85 en in Brabant 36 huisartsen deel aan de huisartsopleiding.

De werving van de huisartsen is niet alleen een enorme inspanning voor de capaciteitsgroep Huisartsgeneeskunde, maar is ook voor het veld een enorme belasting. Huisartsen wordien bovendien met grote regelmaat gevraagd deel te nemen aan wetenschappelijk onderzoek. We hebben bij de werving veel goodwill nodig omdat de beloning die we huisartsen kunnen bieden voor hun onderwijsinzet beperkt is. Bovendien merken we dat huisartsen hun extra ruimte die beschikbaar was voor onderwijs nu ter beschikking stellen aan de praktijkondersteuner, omdat daarvoor vergoeding bestaat. Huisartsen hebben dan geen ruimte meer voor studenten. Natuurlijk zijn er ook voordelen aan de deelname aan het onderwijs. Zo blijken (thuis)artsen die naast de zorg andere taken vervullen meer plezier in huri werk te hebben. Huisartsen geven ook aan dat de ontmoeting met studenten of huisartsen im opleiding hun fris, actief en scherp houdt.

Het jaarlijks congres van het Nederlands Huisartsen Genootschap draagt dit jaar de titel "Verborgen talenter" en wil huisartsen stimuleren hun talenten, onder andere op onderwijsgebied, in te zetten. $1 k$ hoop na dit congres de komende jaren op nog meer huisartsen te kunnen rekenen.

Binnen dit uitgebreide veld is er nog een kleinere groep huisartsen en praktiken warmee de capaciteitsgroep Huisartsgeneeskuinde een hechte relatie heeft: de academische huisartspraktijken.

De basisgedachte was dat het voor de verdere ontwikkeling van de huisartsgeneeskunde noodzakelijk was te beschikken over een aantal huisartspraktijken waar zorg, zorgontwikkeling, onderwijs en wetem- 
schappelijk onderzoek vervochten zouden zijn en ten dienste van elkaar zouden staan ${ }^{\text {in }}$. Dat geheel naar analogie van een academisch ziekenhuis. Rond 1985 heeft de Faculteit Geneeskunde besloten dere ontwikkeling te ondersteunen en heeft specifieke formatie daartoe beschikbaar gesteld. Met een aantal huisartspraktijken zijn contracten afgesloten over hun bijdrage aan onderwijs, registratie ten behoeve wan onderzoek, en onderzoeksdeelname. Er werd echter geen geld beschikbaar gesteld voor zorgontwikkeling. Dat was immers geen facultaire taak.

Stapsgewijs is het netwerk tot stand gekomen: 27 huisartspraktijken verspreid over Limburg: van Maastricht tot aan Venlo. Het totale aantal patiënten is ruime 125.000. Alle praktijken nemen deel aan het onderwijs. Er zijn 22 praktijken die deelnemen aan het RegistratieNet Huisartspraktijken waarvan de doelstelling en opzet reeds eerder verduidelijkt zijn. Van de 62 huisartsen werkzaam in de academische praktijk zijn er 14 gepromoveerd. In de periode 1995-2003 werd bijgedragen aan circa 450 veelal internationale wetenschappelijke publicaties.

Het mag duidelijk zijn dat de huisartsen uit de academische praktijken een forse bijdrage geleverd hebben aan de ontwikkeling van de huisartsgeneeskunde. Maar het bleef natuurlijk wringen dat er geen formatie was woor de ontwikkeling van de zorg temeer omdat transmurale zorg - ketenzorg steeds nadrukkelijker in de belangstelling kwam. Gelukkig kunnen we nu, al is het op bescheiden schaal, deze zorginnovatie projecten structureel gaan opzetten en uitvoeren, dankzij de ondersteuning van het azM.

Het is de bedoeling dat de academische praktijken een ontwikkelfunctie hebben met name op het gebied van de zorg en daarnaast de essentiële taken op het gebied van onderwijs, en registratie binnen het RNH blijven vervullen. Deze praktijken testen en evalueren nieuwe prom tocollen of zorgvoorzieningen, en dienen ma een positieve evaluatie andere praktijken te helpen bij het maken van de implementatiestap. De verspreidingsfunctie is een essentieel onderdeel van hun taak. Bij de verdere uitwerking van de onderwerpen woor zorginnovatie wordt uiteraard afstemming gezocht met BZe VII, de afdeling Transmurale Zorg van het $a z M$. Op deze wijze wordt de ketenzorg verder op gang gebracht.

Het huidige netwerk, waarin alle praktijken nog zelfstandig zijn met hun eigen maatschap, bestuur, administratle, is in beweging zowel ten aanzien wan de taakstelling als de beheersvorm. 
Praktijken moeten overwegen of ze de structurele zorginnovatietaak ambiëren en kunnen opnemen in hun praktijkprofiel.

Het is tevens een goede gelegenheid om te onderzoeken welke beheersvorm voor deze groep praktijken het meest geschikt is, waarbij het letwat vrijblijvende karakter van de samenwerking vervangen wordt door de kracht wan het netwerk als eenheid.

\section{Internationalisering}

Toen deze instelling nog Rijks universiteit Limburg heette, werd gekscherend wel eens gesproken over de Reisuniversiteit Limburg. En het motto van de Universiteit luidt Internationaal en Innovatief. Want internationaal zijn we. Niet alleen op Facultair niveau middels de al jarenlange betrokkenheid bif het Netwerk van community oriented schools dat nu als The Network Towards Unity for Health bekend staat. Maar ook onze eigen capaciteitsgroep neemt deel aan veel internationalle netwerken zoals

- De EGPRN, een Europees netwerk voor huisartsgeneeskundig onderzoek, waarvan het secretariaat vanaf de oprichting in Maastricht gevestigd is.

- Euract, een Europees netwerk voor docenten huisartsgeneeskunde. Maastricht levert de Nederlandse vertegenwoordliger in dat netwerk.

- EQUIF, de Europese vereniging voor onderzoek naar de kwaliteit van huisartsgeneeskundige zorg gestart vanuit Nijmegen/Maastricht.

- The Brisbane Initiative, een internationale samenwerking voor de opleiding van huisartsgeneeskundige onderzoekers, waarvan de voorzitter en de ondersteuning door Maastricht geleverd worden.

Verder zijn medewerkers als consultant actief in veel Oast- Europese landen zoals Hongarije, Bulgarije maar met name in Roemenië waar we de ontwikkeling van huisartsgeneeskundig onderzoek zeer krachtig bevorderen. Uiteraard nemen onderzoekers van onze groep deell aan internationale onderzoeksprojecten.

Studenten geneeskunde weten via de Primary Health Care stages, die door onze capaciteitsgroep in alle continenten worden aangeboden, de weg naar het buitentand te vinden. Van de studenten die in het buitenland een stage gaat lopen doet 20 in $25 \%$ dat via huisartsgeneeskunde en daarmee voeren we de ranglijst aam.

Huisartsgeneeskunde Masitricht heeft een goede internationale naam en dat moet zo blijuen. 
Als $u$ goed heeft opgelet weet $u$ hoeweel landen ik inmiddels heb genoemd. Wellicht is het $u$ opgevallen dat ik Belgie en Duitsland, onze directe buurlanden in deze Euregio, niet genoemd heb. Hebbern we dan geen contacten met België? Zeker wel. We hebben zelfs een gezamen lijke opleidingscursus Vlaanderen/Nederland woor huisartsgeneeskundige onderzoekers. Mijn collega hoogleraar Frank Buntinx is tevens hoogleraar in Leuven. Met Duitsland hebben we wetenschappelijke contacten in Kiel, Berlijn. Heidelberg en Göttingen, maar niet in de directe grensstreek. De vraag kan gesteld worden waarom we geen studenten naar België en Duitsland sturen in plaats van naar Noord Brabant. Met het openbaar wervoer blijkt dat "dichtbij" vaak lange reistijden oplevert. De Euregio bestaat wat vervoer betreft nog wit drie stukken. En dat geldt ook voor de gezondheidszorg. De positie van de huisarts in de zorgsystemen van beide landen is zo verschillend van de Nederlandse, dat huisartsgeneeskundige stages of de opleiding tot huisarts woorlopig niet daar gerealiseerd kunnen worden.

Ten aanzien van de praktijkcontacten in jaar 3 waarbij de patiènt en zijn ziekte het startpunt is voor het leerproces en andere aspecten zoals communicatie en lichamelijk onderzoek een belangrijke rol spelen is het de moeite waard de Euregio optie te exploreren. We moeten dan goed bezien of de aspecten die samenhangen met chroniciteit, een essentieel thema in jaar 3 , well voldoende aan bod blijven komen.

Ten aanzien van onderzoek moeten we nog nadrukkelijker nagaan of bepaalde onderzoeksvragen ook beantwoord zouden kunnen worden door Belgische of Duitse deelnemers. De Euregio verdient kort gezegd meer aandacht, al klinkt een reisje naar Hasselt niet echt internationaal.

\section{Afsluiting}

Ik ga nu naar de afslluiting van mijn betoog. lk heb u meegenomen langs de veranderingen die in de Huisartsemzorg te verwachten zijn, en hebt $u$ een indruk gegeven van de activiteiten en plannen wan onze capaciteitsgroep. Dat beeld is bij lange na niet volledig.

Ook had ik 3 boodschappen voor $u$. Ik zal ze kort samenvatten.

Ik had voor de academische huisartsen de boodschap dat het netwerk van academische huisartspraktijken een hechtere eenheid moet worden.

Een tweede boodschap was: de nascholing van huisartsen moet echt anders. 
Mijn eerste en voor welen wan u ook de belangrijkste boodschap:

De huisarts blijft Er komen grotere huisartsenzorg voorzieningen met andere goed opgelelde professionals die taken van de huisarts overnemen.

\section{Dames en Heren,}

Op het einde van deze rede past het om openbaar dank te zeggen. Gezlen de tijd zal ik mij beperken.

Ik dank het College van Bestuur van de Universiteit Maastricht en het Bestuur van de Faculteit der Ceneeskunde voor het vertrouwen dat ze in mij stellen. Om diezelfde reden dank ik ook de Raad van Bestuur van het Academische Ziekenhuis Maastricht.

Het doet mij veel genoegen dat ik vanaf deze plaats Wim Brouwer kan bedanken. Beste Wim, jij was als hoogleraar Huisartsgeneeskunde lid van de kernstaf van de Medische Faculteit Maastricht in oprichting. De sterke positie van huisartsgeneeskunde in het Curriculum van de Faculteit Geneeskunde is grotendeels jouw verdienste. Daarmalast heb je in 1980 met het symposium "Faculteit en eerste lijn" de aanzet gegeven tot de academisering van de huisartsgeneeskunde ". Het gaat wellicht langzamer dan jij (en ik) dachten, maar zoals ik al betoogd heb: er wordt vooruitgang geboekt. Tenslotte ben je er ook nog verantwoordelijk voor dat ik in Geulle als huisarts aan de slag ben gegaan. En ik moet zeggen dat ik daar geen spijt van heb.

Cees de Geus, jij hebt me betrokken bij het onderzoeksproject "Verslaglegging en Registratie in de Huisartspraktijk" en daarmee richting gegeven aan mijn wetenschappelijke carrière. We hebben samen een belangrijke ontwikkelingsfase van dat project doorgemaakt. Het brengt herinneringen boven aan enerverende tijden en opportunistische bestuurders. Ik heb veel geleerd van de wijze waarop je daarmee omging. Mijn promotor André Knottnerus heeft mij de gelegenheid geboden mijn eigen weg te vinden in de wetenschap. Altijd beschikbaar woor overleg. een stimulerende ondersteuning vanuit een brede kijk op de wetenschap. Ik prijs me gelukkig dat ik bij je ben gepromoveerd en dat je naast je voorzitterschap van de Cezondheidsraad onderzoekers blijt begeleiden binnen onze capaciteitsgroep.

Tenslotte dank ik mijn voorganger Harry Crebolder.

Beste Harry, soms denk ik wel eens: "jij hebt gezaaid, ik mag oogsten". De dingen die nu bereikt zijn daar heb jij heel veel moeite voor gedaan en in 
enkele gevallen hard voor gevochten. $k$ dank je voor de mogelijkheden die je me gaf om mezelf verder te ontwikkelen. Ik weet dat ik zelf ook zal moeten zaaien.

Jan van Ree, Richard Grol, Frank Buntinx, Onno van Schayck en Geert Jan Dinant, mijn andere collega hoogleraren in de capaciteitsgroep dank ik leder voor hun eigen bijdrage op verschillende momenten.

ik weet dat ik op hen kan rekenen net zaals op alle medewerkers die hun thuisbasis hebben bij de capaciteitsgroep Huisartsgeneeskunde. Ik stel jullie bereidwilligheid om samen te werken zeer op prijs. De medewerkers van Bze Vll, de transmurale afdeling van het azM met haar directeur dr Hans Fiollet hebben mij gastvrij ontvangen. Onze samenwerking kan nog verder groeien.

Het huisartsgeneeskundige ambacht heb ik geleerd bij Bert ten Berge; huisarts te Maasniel. Huisarts ben ik in Geulle geworden waar ik met lacques Kuijpers heb mogen samenwerken. Hij heeft mij de ruimte geboden mijn ambitie om naast de patiëntenzorg ook onderwijs en onderzoek te combineren in zijn en later onze huisartspraktijk waar te maken. Helaas hebben we te vroeg afscheid van hem moeten nemen maar ik wil op dit voor mij belangrijke moment mijn dankbaarheid uitspreken.

De collegae van de Huisartsengroep EIsloo-Geullie dank ik voor dle inspirerende en voorbeeldige samenwerking. Onze Hagro heet eigenzinnig te zijn. Jullie zien wat daarvan het resultaat is. $k$ kom nu bij mijn collegae in de praktijk, mijn partners in de maatschap, mijn maatjes Paul Zwietering. Jean Muris en sinds kort ook Ramon Ottenheijm. Onze assistentes en oud assistentes Marieke, Esther, Yvanne en Marie Louise. Ik dank jullie en hoop nog lang op jullie te kunnen rekenem.

Huisartsgeneeskunde is ook Gezinsgeneeskunde en mijn gezin, zowell dat waar ik vroeger als kind toe behoorde, als het huidige waar ik vader ben, zijn mij dierbaar evenals de familieleden daarom heen.

Henriette, je geeft me de ruimte mar stelt ook grenzen. Gelukkig maar. Onze kinderen Maarten, Evelien (beide hier in de zaal) en Stefanie (ver weg in Boston) vinden me soms oud. Malar zij houden me jong.

kk ben een gelukkig mens.

Ik heb gezegd. 


\section{Literatuur}

1. Eddy Houwart

Het Hoge Woord: De huisarts sterf uit

Historisch Nieuws blad 26-8-2003

2. Prof dr Chis van Weel (interview)

Nederlandse Husartsenzorg oogst lof in buitenland

Arts \& Auto; 10, 2003

3. Joke Lanphen (interview)

Huisartsen hebben een goede peptalk nodig

De Huisarts; juni 2003 , nr 6

4. Kwallteit Huisartsenzorg in gevaar

Persbericht Nederlands Huisartsen Genootschap als reactie op

Subsidiebeleid VWS, 22 september 2003

5. Basistakenpakket van de Huisarts

LHV Vademecum, 1987

6. Functie en Taakomschrijwing Huisartsenzorg

Conceptrapportage Werkgroep, jull 2003

7. Toekomstvisie Huisartsenzorg

$\mathrm{NHI}$, Utrecht, 2002

8. Van Verzekeraar naar Zorgverlener

Corina de Feijter

De Huisarts, mel 2003 nn. 5

9. Duizand bloemen in én kleurrjk pakket

Op weg nar een georganiseerde eerste lijn

Stichting Toekomstscenario's Gezondheidszorg (5TO)

Elsevier Gezondheidszorg, Maarsen. 2003

10. Taakherschikking in de gezondheidszorg

Raad voor de Volksgezondheid en Zorg

Zoetermeer, 2002 
11. AP Timmers ea

Een deskundig alternatief. Praktijkondersteuner moet voonal kleine kwalen behandelen

Medisch Contact (57) nr 46:1701-1704

12. B Vrithoef

Is it justifiable to treat chronic patients by nurse specialists? (Thesis) Universitaire Pers Maastricht, Mastricht, 2002

13. De zeeffunctie voor de huisarts

Voor doktersassistenten is triage niets nieuws

Arts en Auto (12) 2003:62

14. De Arts wan Straks

wWw.deartsvanstraks.nl

15. De Zorg van Morgen. Flexibiliteit en samenhang Advies van de Commissie Implementatie Opleidingscontinuüm en Taakherschikking

Ministerie vam VWS, Den Haag, juli 2003

16. Het systeem voor accreditering is an verbetering toe Sjoerd Hobma

Huisarts en Wetenschap $46(6)$ mel 2003,298

17 Linking assessment to learning: a new route to quality assurance in medical practice

RS Handfield-. Jones et all

Medical Education 2002:36:949-958

18. Continuing Professional Development in Primary Health Care. Quality Development integrated with Continuing Medical Education Policy document of EQUIP and Euract, 2002

19. Terug naar die Ardennen. Een evaluatie van twee nascholingscursussen volgens het Warfum madel.

FM Metsemakers, PAG Bouhuijs en GMH Beusmans

Huisarts en Wetenschap 1983; 26:189-193 
20. Putting Practice into Research

Irene Fraser, David Lanier, Fred Hellinger, and John M. Eisenberg HSR: Health Services Research 37: (February 2002) XIII - XXVI

37. Di W Brouwer, dr M Romme red

Faculteit en eerste lijn

Bohn, Scheltema \& Holtema, Utrecht/Antwerpen 1981 
